\title{
Irrigation Practices on Rice Crop Production in Arsenic-Rich Paddy Soil
}

\author{
Mon-Lin Chou, Jiin-Shuh Jean, ^ Guo-Xin Sun, Chwen-Ming Yang, \\ Zeng-Yei Hseu, Sheng-Feng Kuo, Hong-Yang Tseng, and Yuai-Jen Yang
}

\begin{abstract}
Irrigation and water management are important cultivation practices, controlling rice crop production and regulating As concentration in both paddy fields and rice plants (Oryza sativa L.). This study investigated the impacts of various types of irrigation practices with As-contaminated groundwater on the extent of arsenic accumulation within rice plant parts during development and rice crop production at maturity. Three types of irrigation practices were applied to As-rich paddy fields: flooded irrigation, aerobic irrigation, and alternate wetting and drying irrigation (AWDI). The arsenic accumulation in various plant parts was monitored at 40 , $54,68,82,96$, and $110 \mathrm{~d}$ after transplanting in the first (with 'Tainong 84') and the second (with 'Tainan 11') cropping seasons of 2013. Results show that the arsenic concentration in different parts of rice plants varied with growth stage and irrigation practices in both cropping seasons. There was a seasonal fluctuation of arsenic concentration within rice plants during plant development with flooded irrigation, which had the largest amount of irrigation input. Lower levels of As in rice were found in AWDI and aerobic irrigation than in flooded irrigation. Different irrigation practices can change the oxidation and reduction conditions of the paddy field, which lead to As release or absorption in the soil, thus influencing the uptake of As by plants.
\end{abstract}

M.-L. Chou, J.-S. Jean, and Y.-J. Yang, Dep. of Earth Sciences, National Cheng Kung Univ., Tainan 70101, Taiwan; G.-X. Sun, State Key Lab. of Urban and Regional Ecology, Research Center for EcoEnvironmental Sciences, Chinese Academy of Sciences, 18 Shuangqing, Beijing, 100085, China; C.-M. Yang, Division of Crop Science, Taiwan Agricultural Research Institute, Taichung City 41362, Taiwan; Z.-Y. Hseu, Dep. of Environmental Science and Engineering, National Pingtung Univ. of Science and Technology, Pingtung 91201, Taiwan; S.-F. Kuo, e Dep. of Resource Environment and Green Industries, Univ. of Kang Ning, Tainan 70901, Taiwan; and H.-Y. Tseng, Dep. of Atmospheric Sciences, Chinese Culture Univ., Taipei 11114, Taiwan. Received 10 Apr. 2015. Accepted 17 July 2015. *Corresponding author (jiinshuh@mail.ncku.edu.tw).

Abbreviations: As(III), trivalent arsenite; As(V), pentavalent arsenate; AWDI, alternate wetting and drying irrigation; DAT, days after transplanting; DMA, dimethylarsinate; DO, dissolved oxygen; EC, electrical conductivity; Eh, oxidation-reduction potential; MMA, monomethylarsonate; TDS, total dissolved solids.

A RSENIC-CONTAMINATED RICE and water are the major sources of As intake for Asians. In the Chianan Plain in southwestern Taiwan, naturally occurring As is plentiful in groundwater, on which rice cultivation depends for irrigation, particularly in the dry period when surface water from rivers, dams, ponds, and other resources in this area is limited. Because long-term irrigation of As-contaminated groundwater may cause an increase in the As concentration in agricultural soil and crop plants (Abedin et al., 2002a, 2002b; Rahman et al., 2007a, 2008), the Chianan Plain is considered as a high-risk region for growing rice.

Contamination of food and drinking water with hazardous substances is an issue of global concern (Kuramata et al., 2011). Among such substances, As is recognized as a Class 1 human carcinogen (IARC, 2004). Arsenic concentrations and speciation

Published in Crop Sci. 56:422-431 (2016).

doi: 10.2135/cropsci2015.04.0233

(C) Crop Science Society of America | 5585 Guilford Rd., Madison, WI 53711 USA

All rights reserved. 
in soil water are strongly influenced by the redox conditions and water management in paddy fields (Roberts et al., 2011). In an anaerobic environment, such as in paddy soils, the inorganic trivalent arsenite $[\mathrm{As}(\mathrm{III})]$ has high mobility, and thus rice is more efficient than other cereal crops in assimilating As into its grains (Williams et al., 2007). Therefore, investigating the impacts of As-rich soil and As-contaminated irrigation water on As accumulation and metabolism in rice has drawn a lot of attention in recent years (Rahman et al., 2007b; Chou et al., 2014). Arsenite is present in paddy soils under flooded conditions as a result of As accumulation from irrigated groundwater, and this As can be taken up from soil, accumulating in roots and being transported to the shoots (stems plus leaf sheaths) and leaf blades of rice plants (Chou et al., 2014).

It has been reported that growing rice in a deficit irrigation environment reduces As uptake in various parts of plants, whereas a practical water management of the system must not significantly reduce grain yield (Sarkar et al., 2012). A management practice widely adopted for irrigated lowland rice, AWDI has been proven to reduce water consumption and greenhouse gas emissions while maintaining yields (Seckler, 1996; van de Hoek et al., 2001; Richards and Sander, 2014). The practice is defined by the periodic drying and reflooding of the rice field; irrigation water is applied a few days after the disappearance of ponded water. With alternating flooded and nonflooded conditions, grain yield is maintained while water use, greenhouse gas emissions, and As levels in rice are reduced (Linquist et al., 2015). In anaerobic soils, the reductive mobilization of As increases the phytoavailability and uptake of As in rice (Meharg and Zhao, 2012). According to Takahashi et al. (2004), arsenic in irrigation water is incorporated into Fe (hydr)oxide in soil during the nonflooded period, and it is quickly released from soil to water during the flooded period because of the reductive dissolution of the As-bearing Fe (hydr)oxide phase and reduction of As from pentavalent arsenate $[\mathrm{As}(\mathrm{V})]$ to As(III). Thus, flooded rice may contain high As concentration compared with that in other grain crops. However, more knowledge about the mobility of As within rice plants under the impacts of irrigation practices is required for the development of measures to reduce the As concentration in rice grain while maintaining normal production of rice. Arsenic concentrations and speciation in soil pore water of flooded paddy fields (or not flooded) are strongly influenced by bacterially induced dynamic biogeochemical processes (Masscheleyn et al., 1991; Garnier et al., 2010), as evidenced by the comparison between As release in poisoned and not poisoned medium (van Geen et al., 2006). During the rice growing period, the elevated As concentrations in soil pore water and their variations result from three main factors: (i) dynamic biogeochemical processes (leading to the reductive dissolution of
As-bearing hydroxides), (ii) the amount of As in soil that accumulates over years of irrigation practices, and (iii) the As concentration of irrigated water used to grow the rice (Abedin et al., 2002a; Khan et al., 2009; Garnier et al., 2010). Under aerobic conditions, only the first main factor (i) will be modified through the change of redox conditions (Xu et al., 2008).

Four species of As are commonly reported in rice grain: $\operatorname{As}(\mathrm{III}), \operatorname{As}(\mathrm{V})$, monomethylarsonate (MMA), and dimethylarsinate (DMA; Williams et al., 2005). Arsenic in groundwater is mainly inorganic, with arsenate comprising about 50\% of the total As (Samanta et al., 1999). Inorganic As is generally more toxic than are methylated As compounds (Schoof et al., 1999). Peripheral vascular gangrene, also known as blackfoot disease (BFD), was first reported in Chianan Plain in southwestern Taiwan in the 1960s (Tseng et al., 1961). It was due to the consumption of deep well water with high As concentration (Tseng, 1977, 1985). Although As-contaminated groundwater is not used for drinking in Taiwan currently, it is still widely applied for irrigation purposes, including growing rice. However, few studies have examined the impacts of irrigation practices on rice production, As accumulation and its partitioning in rice plants, and As species in brown rice, collectively. The underlying mechanism how irrigation and water management control rice production and regulates As concentration in rice plants is still unclear. Arsenic toxicity in rice can be alleviated via the use of alternative irrigation sources, suitable agronomic practices, as well as appropriate irrigation practices.

This study investigated the impacts of irrigation practices on the As concentration in different parts of rice plants and grain production. The underlying mechanisms involved in regulating the uptake and mobilization of As in soil and within rice plant parts and possible strategies for minimizing As accumulation in rice are elucidated. Such information is required for the agricultural authority to formulate policies for enhancing water productivity and reducing the possible accumulation and distribution of As in rice plants.

\section{MATERIALS AND METHODS Experimental Layout}

Field experiments were performed on an experimental farm $\left(23^{\circ} 12^{\prime} 4.02^{\prime \prime} \mathrm{N}, 120^{\circ} 10^{\prime} 50.7^{\prime \prime} \mathrm{E}\right)$ in the Hsuehchia District of Tainan City in southwestern Taiwan. The area is situated at a subtropical latitude, where the weather is hot and humid in the wet season (April to September) with moderate temperature and low rainfall in the dry season (October to March). The experiments were conducted in the first (from February to June) and the second (from July to November) cropping seasons of 2013, a conventional two-crop system used locally. Since both cropping seasons occupy portions of dry and wet seasons, groundwater was used for rice irrigation in both cropping seasons. To provide various amounts of irrigation water and dissimilar levels of As in the paddy fields, three irrigation practices were employed. 


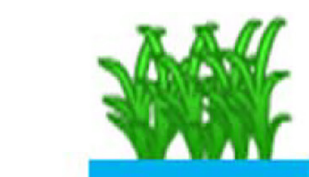

Flooded irrigation
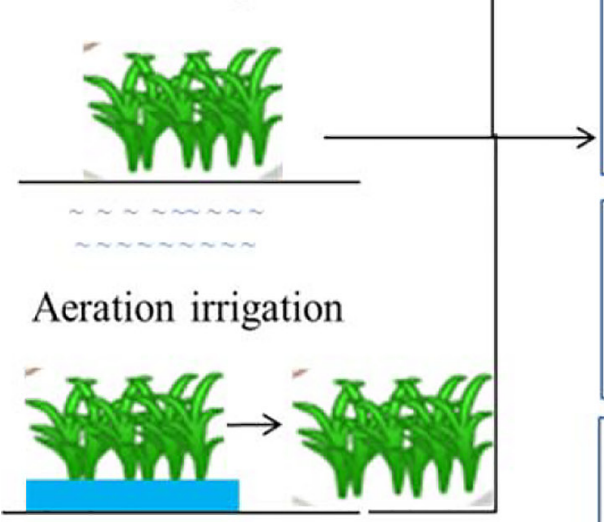

Alternative wetting and

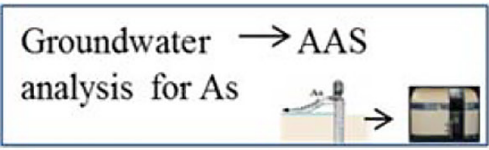

Soil $\rightarrow$ HG-AFS analysis for total As and As speciations


Rice Grain $\rightarrow$ HPLC-ICPMS analysis for As speciations

\section{drying irrigation}

Figure 1. Schematic diagram giving overview of all experiments and their roles in this study. AAS, atomic absorption spectroscopy; HG-AFS, hydride generation atomic fluorescence spectrometry; HPLC-ICP-MS, high performance liquid chromatography-inductively coupled plasma mass spectrometry.

To allow the establishment of a rice population, the irrigation practices were initially flooded and started 45 days after transplanting (DAT) until $10 \mathrm{~d}$ before the harvest. Both cultivars, Tainong 84 and Tainan 11, are japonica rice with different growth types and rice qualities. They are two popular cultivars grown locally, but Tainong 84 was planted in the first cropping season and Tainan 11 was grown in the second cropping season. In flooded irrigation, the paddy field was continuously irrigated to a depth of 5 to $10 \mathrm{~cm}$ above the surface of the soil. For AWDI, water was flooded to a depth of 5 to $10 \mathrm{~cm}$ above the soil surface after the disappearance of ponded water. For aerobic irrigation, water was applied to cover the paddy field to a depth of 5 to $10 \mathrm{~cm}$ when soil moisture tension reached $30 \mathrm{kPa}$ at a depth of $15 \mathrm{~cm}$ (Fig. 1). Soil moisture tension was measured and monitored using soil tensiometers buried in the soil, two per plot, in conjunction with a water retention curve. Each irrigation practice had three replicated plots, with a plot area of 3 by $3 \mathrm{~m}$ and a planting density of 0.30 by $0.15 \mathrm{~m}$ (column $\times$ row). Plots were separated with isolation berms to avoid interference between plots. Three to four hills were sacrificed from each plot in every sampling to measure their growth traits, including plant height and fresh and dry weights of roots, leaf blades, and shoots. Changes in grain weights were monitored during the grain-filling stage, and grain production per unit area and 1000-grain weight were measured at the harvest. The weather conditions of the Hsuechia experimental site were automatically recorded from an automated weather station which was set up at the site. Between April and October 2013 the temperature and monthly rainfall were automatically recorded.

\section{Sample Collection and Analysis Arsenic Concentration in Irrigation Groundwater}

Samples of irrigation groundwater in the experimental site were collected in the first and second cropping seasons from a shallow tube. The samples were collected on 11 April, 25 April, 9 May, 24 May, 20 June (at the harvest) in the first cropping season, and 14 August, 27 August, 10 September, 26 September, and 10 October (at the harvest). Sampled water was passed through a $0.45-\mu \mathrm{m}$ filter, acidified with concentrated $\mathrm{HNO}_{3}$ until $\mathrm{pH}<2$, and then stored in polyethylene bottles. The bottled samples were brought back to the Hydrogeology Laboratory of National Cheng Kung University, Tainan City, Taiwan, and stored in the dark at $4^{\circ} \mathrm{C}$ before analyses. The irrigation groundwater was analyzed for total As using an atomic absorption spectrophotometer (GF 5000, GBC Scientific Equipment Pty Ltd., Australia). The pH and oxidation-reduction potential (ORP or Eh) were measured using a portable $\mathrm{pH} / \mathrm{ORP}$ /Temp meter (model TS-100, SUNTEX Instruments Co., Ltd., Kaohsiung, Taiwan). An $\mathrm{AgCl}_{2}$ electrode was used to measure the Eh values, which were not corrected relative to the standard hydrogen electrode. The electrical conductivity (EC) and total dissolved solids (TDS) were measured by a handheld conductivity meter (Cond 330i, Wissenschaftlich-Technische Werkstätten GmbH \& Co., Wellhelm, Germany), and dissolved oxygen (DO) was measured by a handheld DO meter (HI 9147, Hanna Instruments, Woonsocket, RI).

\section{Arsenic Concentration in Soil}

The soil samples irrigated with the As-contaminated groundwater were collected from the top soil layer (depth of 0 to $15 \mathrm{~cm}$ ) in each plot, and were sealed in airtight polyethylene bags. The 
soil samples were collected with a hand auger before the experiments (1 May and 1 July 2013). The soil samples were dried in a hot-air oven at $60^{\circ} \mathrm{C}$ until they reached a constant weight, and were then ground to powder, passed through a $2.0-\mathrm{mm}$-pore sieve, and stored in airtight polyethylene bags at room temperature. A modified procedure of Ruiz-Chancho et al. (2005) was adopted for As extraction. An aliquot of $0.1 \mathrm{~g}$ of soil was put into a clean conical flask and then $15 \mathrm{~mL}$ of extraction solvent (1 $\mathrm{M}$ phosphoric acid and $1 \mathrm{M}$ vitamin $\mathrm{C}$ ) was added to this. The ascorbic acid (vitamin C), with antioxidant properties, is used to dissociate the arsenic ions. The flasks were heated at $220^{\circ} \mathrm{C}$ for 30 min (heated to boiling; Ruiz-Chancho et al., 2005). After the solution had cooled down to room temperature, it was filtered through a $0.45-\mu \mathrm{m}$ membrane, diluted to $25 \mathrm{~mL}$ with deionized water, and then analyzed with atomic fluorescence spectrometry (Millennium Excalibur System PS Analytical, UK).

\section{Arsenic Concentration in Rice Plants}

The rice plant samples were randomly sampled to monitor changes in As concentration in various plant parts at 40, 54, 68, 82,96 , and 110 DAT in both cropping seasons. These samples were brought back to the laboratory for further treatments. The rice plant samples were washed with tap water to remove soil and other substances, and then immersed into deionized water for several minutes. After drying in a hot-air oven at $70^{\circ} \mathrm{C}$ for $72 \mathrm{~h}$, dry weights were measured. The dried rice plant samples were stored in airtight polyethylene bags at room temperature with proper labeling. Care was taken to avoid contamination during the measurement procedures. This analysis of the total As in rice plants is based on the work of Chou et al. (2014). Husks were removed from rice grains and then oven-dried at $70^{\circ} \mathrm{C}$. The microwave method was employed to extract the As species from husks and the brown rice of rice grains. An aliquot of $0.2 \mathrm{~g}$ of rice powder was put into $50-\mathrm{mL}$ polyethylene centrifuge tubes, to which $10 \mathrm{~mL}$ of $1 \%$ hydrochloric acid was added, and then left to stand overnight at room temperature. Samples were processed in a microwave (MARS, CEM, Matthews, NC) using a three-stage temperature ramping program. Each stage ramped up to the designated temperature over a 5 -min period; that is, samples were maintained at $55^{\circ} \mathrm{C}$ for $10 \mathrm{~min}$ at Stage 1 , at $75^{\circ} \mathrm{C}$ for $10 \mathrm{~min}$ at Stage 2 , and at $95^{\circ} \mathrm{C}$ for $30 \mathrm{~min}$ at Stage 3. The samples were then cooled and centrifuged $(6000$ $\mathrm{rpm}$ ) for $10 \mathrm{~min}$, and filtered with a $0.45-\mu \mathrm{m}$ membrane. The supernatant was kept at $4^{\circ} \mathrm{C}$ until analysis. The extracts were analyzed for As(III), As(V), MMA, and DMA using Agilent 7500a HPLC-ICP-MS (Sun et al., 2012).

\section{Analytical Quality Control}

All instruments were calibrated using matrix-matched standards. Three duplicates were analyzed for each sample, and the mean values were taken as representatives with an accuracy of 5\% and a precision of $2 \%$. For quality control, three certified reference materials (CRM) of 10010 Chinese rice flour samples were prepared to validate the analysis. Standard reference materials (SRM; item no. 2710) were obtained from the National Institute of Standard Materials and Technology, Gaithersburg, MD. The certified concentration value for As in NIST SRM 2710 is $610 \pm$ $28 \mathrm{mg} \mathrm{kg}^{-1}$. Arsenic recovery for individual samples ranged from 96 to $105 \%$, with an average of $102 \pm 3.5 \%(n=10)$.
Table 1. Characteristics of groundwater $(n=11)$ collected at the Hsuehchia experimental site (mean values were determined from 11 groundwater samples).

\begin{tabular}{lc}
\hline \multicolumn{1}{c}{ Parameter $^{\dagger}$} & Value \\
\hline $\mathrm{pH}$ & $7.2 \pm 0.1$ \\
$\mathrm{EC}, \mu \mathrm{S} \mathrm{cm}{ }^{-1}$ & $2058 \pm 123$ \\
TDS, $\mathrm{mg} \mathrm{L}^{-1}$ & $985.6 \pm 57.3$ \\
Salinity, \%o & $0.9 \pm 0.1$ \\
$\mathrm{DO}, \mathrm{mg} \mathrm{L}^{-1}$ & $0.9 \pm 0.6$ \\
Eh, $\mathrm{mV}^{-1}$ & $-79 \pm-16$ \\
As(III), $\mu \mathrm{g} \mathrm{L}^{-1}$ & $90.1 \pm 9.2$ \\
As(V), $\mu \mathrm{g} \mathrm{L}^{-1}$ & $20.2 \pm 4.1$ \\
Average total As, $\mu \mathrm{g} \mathrm{L}^{-1}$ & $110.4 \pm 10.2$ \\
\hline
\end{tabular}

${ }^{\dagger} E C$, electrical conductivity; TDS, total dissolved solids; DO, dissolved oxygen; Eh, oxidation-reduction potential.

\section{RESULTS AND DISCUSSION Characterization of Groundwater and Soil}

At the Hsuechia experimental site, the maximum and minimum temperatures were recorded to be in the ranges of 31.4 to $35.7^{\circ} \mathrm{C}$ and 15.5 to $23.5^{\circ} \mathrm{C}$, respectively, and the monthly rainfall was measured to be in the range of 0 to $813.2 \mathrm{~mm} \mathrm{mo}^{-1}$, with a total of $535 \mathrm{~mm}$ in the first cropping season and $920.1 \mathrm{~mm}$ in the second cropping season. The average total As in the groundwater at the studied site was $110.4 \pm 10.2 \mu \mathrm{g} \mathrm{L}^{-1}$ (Table 1), higher than the permissible limit $\left(50 \mu \mathrm{g} \mathrm{L}^{-1}\right)$ for irrigation water recommended by the Environmental Protection Administration of Taiwan. Other characteristics of groundwater, including $\mathrm{pH}, \mathrm{EC}, \mathrm{TDS}, \mathrm{DO}$, and Eh, are listed in Table 1. From the ranges of these parameters, the aquifer was in moderate reducing conditions. With fairly low values of DO $\left(<1 \mathrm{mg} \mathrm{L}^{-1}\right)$ and salinity $(0.8$ to $1 \%$ ), the groundwater used for irrigation could be considered as freshwater.

The soil of the experimental site is a sandy loam containing high percentages of sand and organic $\mathrm{C}$, with a high cation exchange capacity (10 to $11 \mathrm{cmol} \mathrm{kg}^{-1}$; Table 2). The range of $\operatorname{As}(\mathrm{V})$ concentration in soil was from 11.4 \pm 1.3 to $13.1 \pm 2.0 \mathrm{mg} \mathrm{kg}^{-1}$, and that of $\mathrm{As}(\mathrm{III})$ was from $2.3 \pm 0.1$ to $3.0 \pm 0.2 \mathrm{mg} \mathrm{kg}^{-1}$. The total As concentration in soil ranged from $13.9 \pm 1.8$ to $16.1 \pm 2.1 \mathrm{mg} \mathrm{kg}^{-1}$ (Fig. 2). The concentrations of $\mathrm{As}(\mathrm{V})$ and $\mathrm{As}(\mathrm{III})$ in soil pore water of flooded paddy fields were $12.2 \pm 0.1 \mathrm{mg} \mathrm{L}^{-1}$ and $92.2 \pm 1.6 \mathrm{mg} \mathrm{L}^{-1}$, respectively, whereas those in nonflooded fields were $9.6 \pm 0.5 \mathrm{mg} \mathrm{L}^{-1}$ and $2.7 \pm 0.3 \mathrm{mg}$ $\mathrm{L}^{-1}$, respectively. The concentration of As(III) in soil pore water of flooded paddy fields was $87 \%$ higher than that of $\mathrm{As}(\mathrm{V})$, and $97 \%$ higher than in nonflooded paddy fields. This indicates that more As(III) was released in soil pore water in flooded irrigation than in aerobic irrigation.

\section{Arsenic Concentration in Rice Plant Parts}

The As concentration in various parts (roots, shoots, and leaf blades) of rice plants collected at different growth stages $(40,54,68,82,96$, and 110 DAT) is plotted in Fig. 3 
Table 2. Characteristics of soil $(n=7)$ collected at the Hsuehchia experimental site.

\begin{tabular}{|c|c|c|c|c|c|c|c|c|}
\hline $\operatorname{Plot}^{\dagger}$ & $\mathrm{pH}$ & Clay & Sand & Silt & Organic C & Texture & $\mathrm{CEC}^{\ddagger}$ & As concentration \\
\hline & &  & $\mathrm{g} \mathrm{kg}^{-1}$ & &  & & $\mathrm{cmol} \mathrm{kg}^{-1}$ & $\mathrm{mg} \mathrm{kg}^{-1}$ \\
\hline $\mathrm{FI}$ & $7.1 \pm 0.1$ & $130 \pm 10$ & $710 \pm 50$ & $150 \pm 10$ & 13 & sandy loam & 10 & $13.9 \pm 1.8$ \\
\hline $\mathrm{Al}$ & $7.1 \pm 0.3$ & $120 \pm 10$ & $720 \pm 30$ & $120 \pm 10$ & 12 & sandy loam & 11 & $16.1 \pm 2.1$ \\
\hline AWDI & $7.2 \pm 0.1$ & $130 \pm 20$ & $710 \pm 20$ & $130 \pm 20$ & 14 & sandy loam & 10 & $14.1 \pm 1.2$ \\
\hline
\end{tabular}

${ }^{\dagger} \mathrm{Fl}$, flooded irrigation; $\mathrm{Al}$, aerobic irrigation; and AWDI, alternate wetting and drying irrigation.

${ }^{\ddagger} \mathrm{CEC}$, cation exchange capacity.

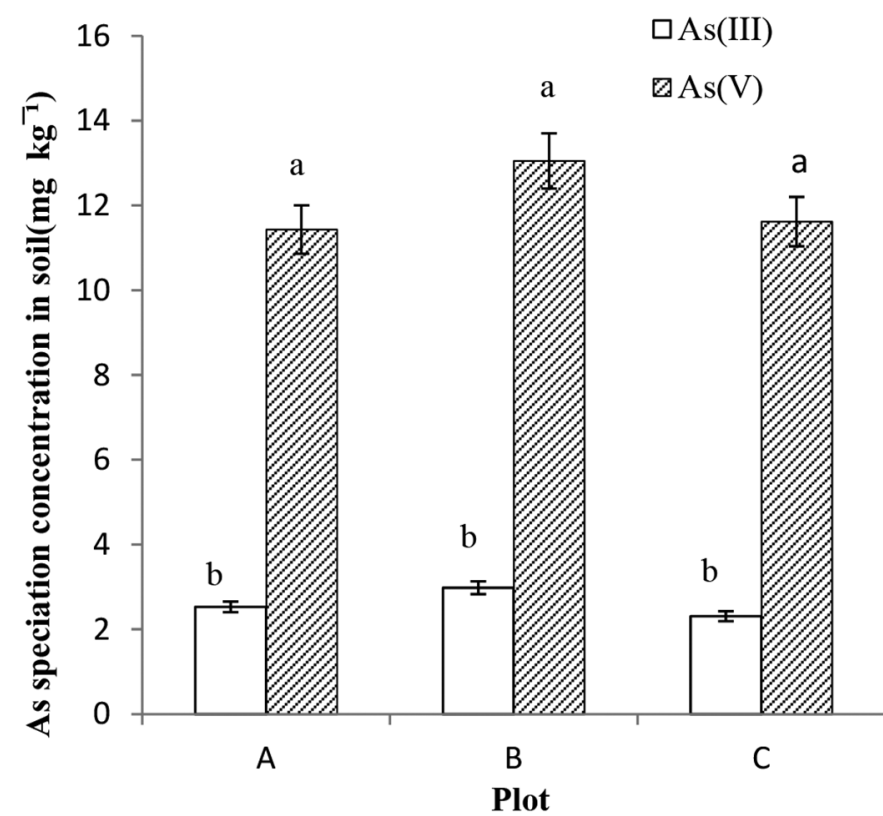

Figure 2. The concentrations of two arsenic species measured in soil of the experimental site. Mean $\pm \operatorname{SE}(n=5)$. The values within each column followed by the same letter(s) are not significantly different at $P<0.05$ by Fisher's LSD test. (A) Flooded irrigation plot. (B) Aerobic irrigation plot. (C) Alternate wetting and drying plot.

and 4. Results show that there was a seasonal fluctuation of As concentration in every part during plant development. In the vegetative tissues, generally the As concentration was in the order: roots $>$ leaf blades $\geq$ shoots. At maturity, the As concentration was roughly in the order: roots $>$ leaf blades $\geq$ shoots $>$ husks $>$ brown rice (Fig. 3-6). Uptaken As mostly accumulated in roots, with a small portion being transported to the aboveground plant parts. Moreover, the As concentration in flooded irrigation-treated plant parts was higher than that for the other two irrigation practices before the harvest, indicating that water-saving practices such as aerobic irrigation and AWDI resulted in lower accumulation of As within rice plants.

Similar results are reported by Marin et al. (1993), Rahman et al. (2004), and Bogdan and Schenk (2012). Other studies (Marin et al., 1993; Abedin et al., 2002a, 2002b; Meharg and Jardine, 2003; Rahman et al., 2007a, 2007b; Chou et al., 2014) pointed out that the partitioning of As within rice plants was in the order: roots $>$ leaves $>$ shoots regardless of the rice variety and cultivation method used in the experiments. Abedin et al. (2002a, 2002b) indicated that
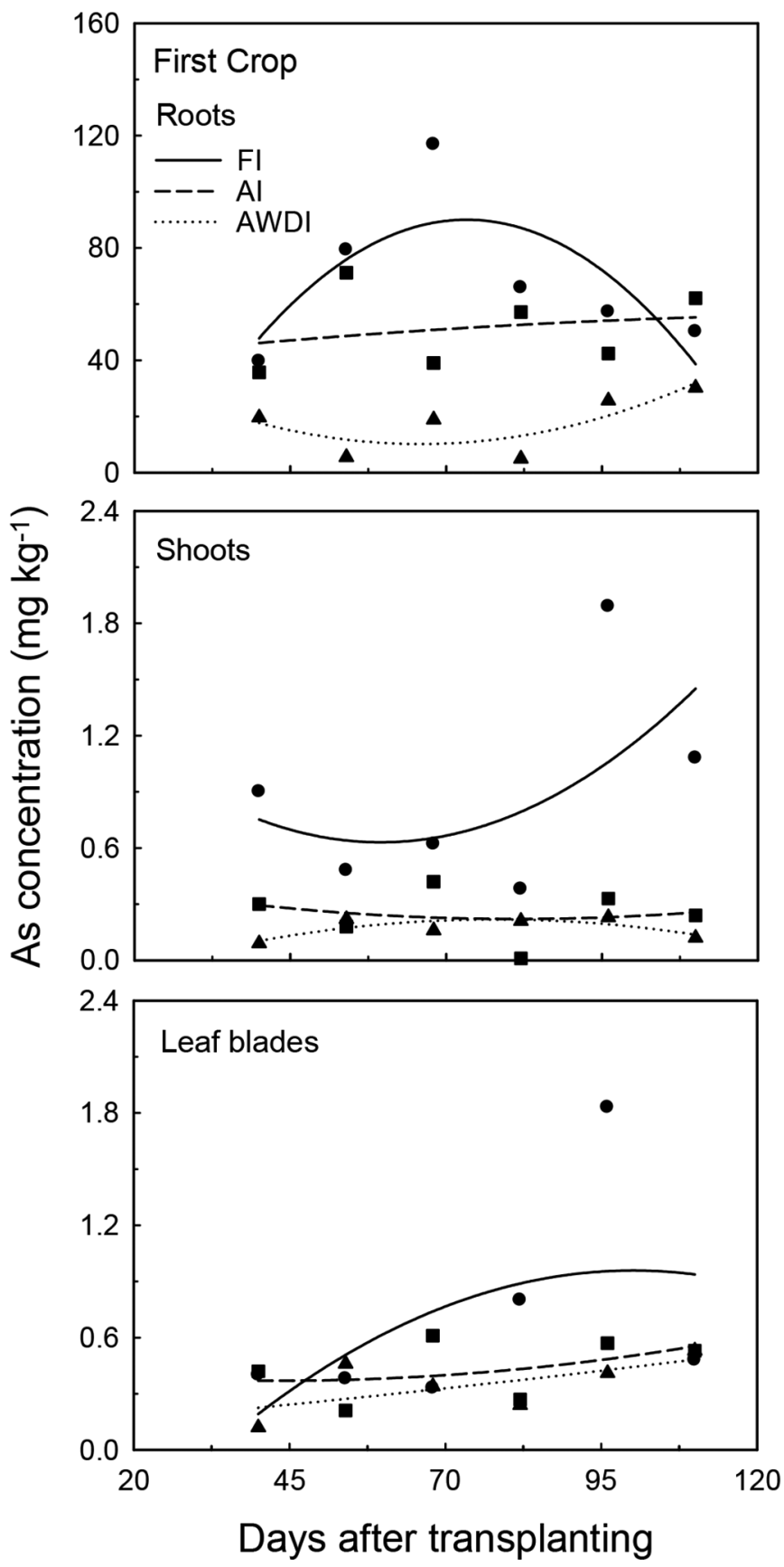

Figure 3. Changes of arsenic concentration in various parts of rice plants: roots, shoots (stems plus leaf sheaths), and leaf blades, for different irrigation practices during the second cropping season of 2013. FI, flood irrigation; Al, aerobic irrigation; AWDI, alternate wetting and drying irrigation. 
(a)
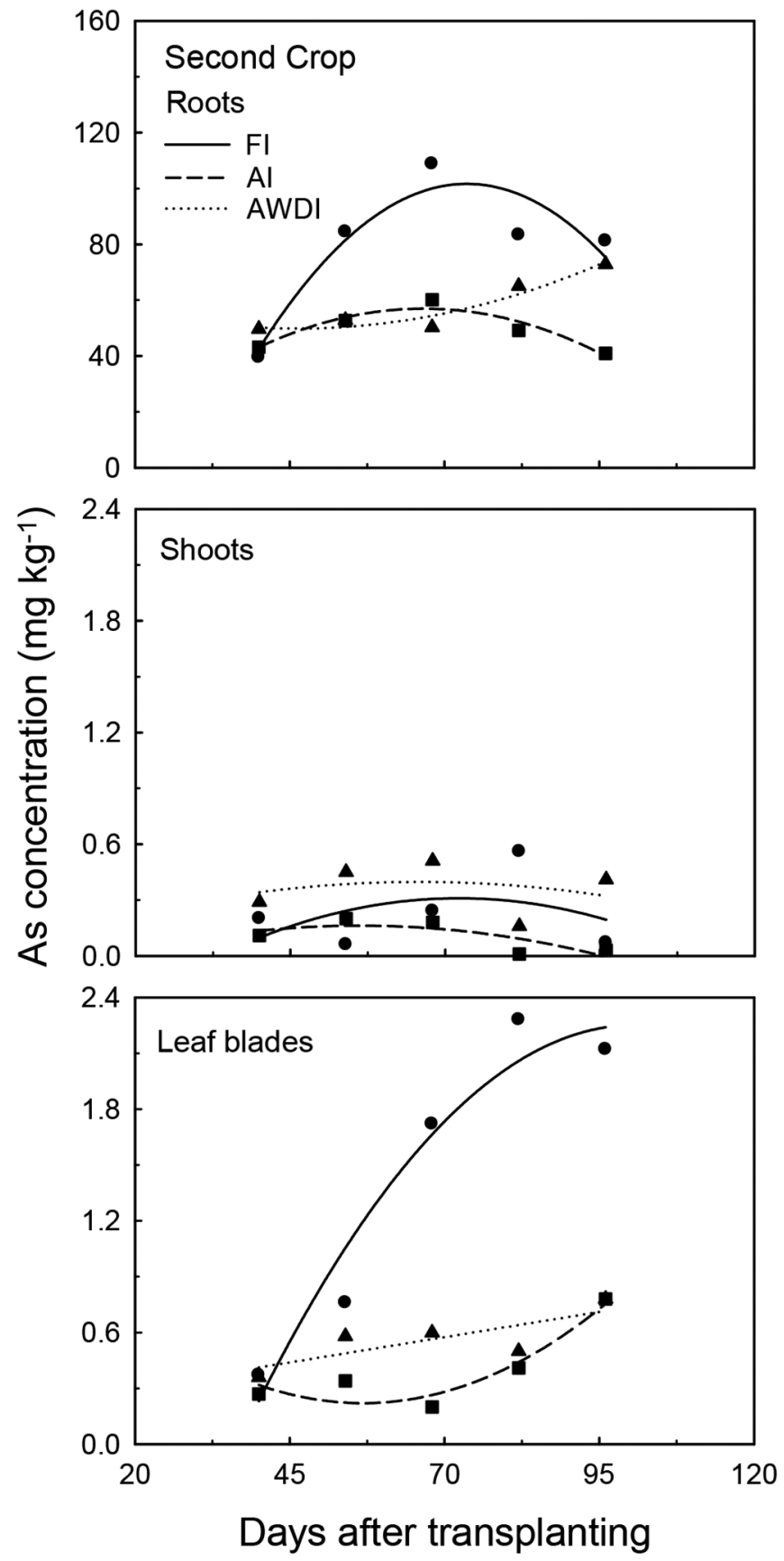

Figure 4. Changes of arsenic concentration in various parts of rice plants (i.e., roots, shoots [stem + leaf sheaths], and leaf blades) for different irrigation practices during the second cropping season of 2013. FI, flood irrigation, Al, aerobic irrigation, AWDI, alternate wetting and drying irrigation.

the concentration of As in rice straws could be up to $92 \mathrm{mg}$ $\mathrm{kg}^{-1}$ when rice plants were irrigated with As-contaminated water while the British statutory permissible limit for As in straw fed to cattle is $0.2 \mathrm{mg} \mathrm{kg}^{-1}$ (Nicholson et al., 1999). They also showed that an increasing concentration of arsenate in irrigation water significantly decreased plant height, grain production, number of filled grains, grain weight, and root biomass, with the As concentration in roots, straws, and rice husks increasing substantially.
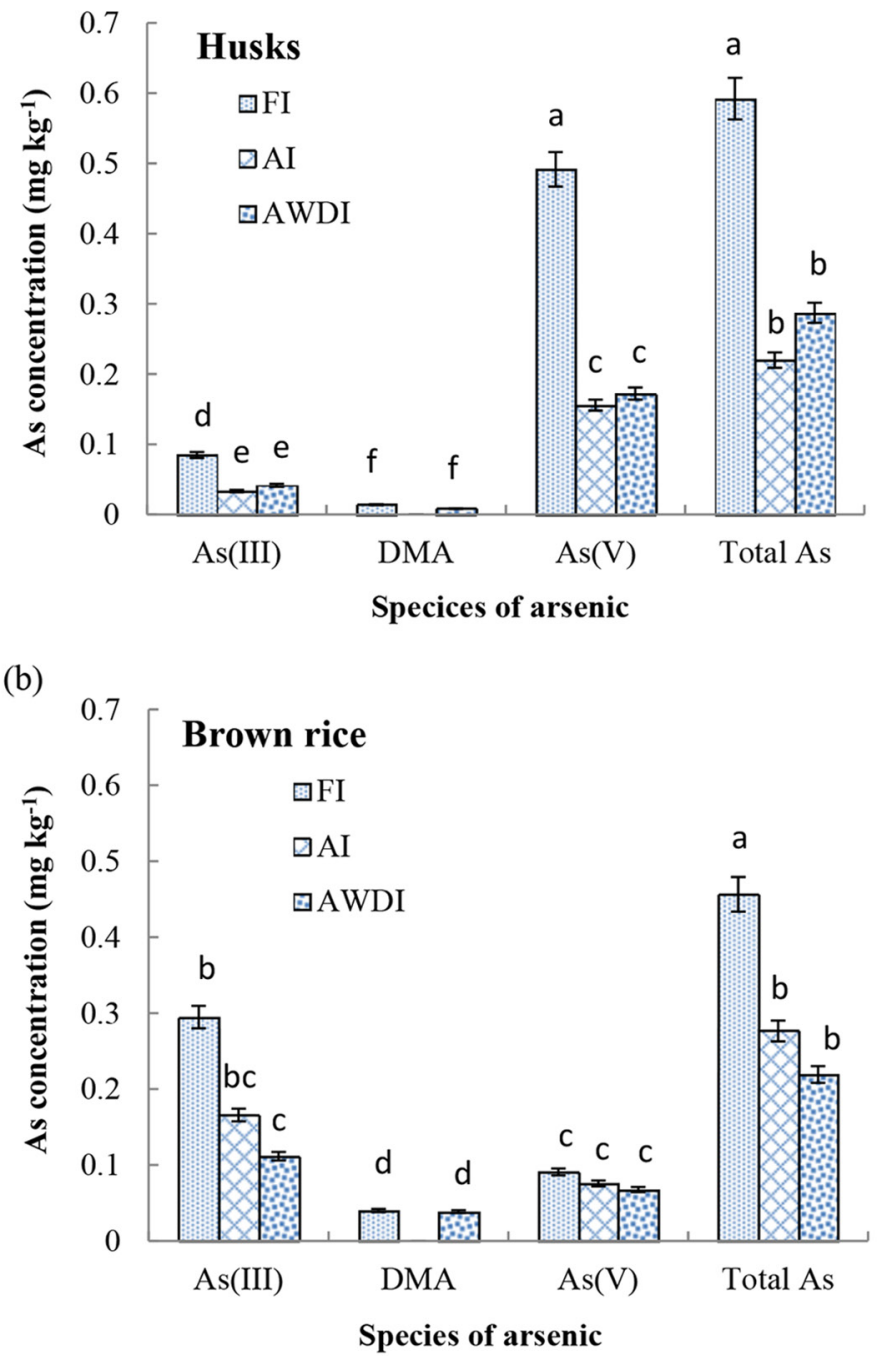

Figure 5. Effects of irrigation practices on arsenic speciation in (a) husks and (b) brown rice of rice plants grown in the first cropping season of 2013. Error bars represent mean \pm SE. Values above each column followed by the same letter(s) are not significantly different according to Fisher's least significant difference test at $p<0.05$. Fl, flood irrigation; Al, aerobic irrigation; AWDI, alternate wetting and drying irrigation; DMA, dimethylarsinate.

In their experimental results, Bogdan and Schenk (2012) showed that, with As-rich irrigation water, flooded paddies provided abundant sources of As to the root zone, contributing to the higher As concentration in the roots. The present study obtained similar results, with roots, leaf blades, and shoots accumulating substantial As in both cropping seasons, particularly roots (Fig. 3 and 4). The As partitioning in the tissues of rice plants was observed to be 97 to $99 \%$ in roots, 2 to $3 \%$ in leaf blades and shoots, and 1 to $2 \%$ in grains (husks and brown rice; Fig. 5 and 6). This is consistent with a report by Rahman et al. (2007b), in which the As distribution in roots, straws, and grains was 96,3 , and $1 \%$, respectively.

This study further indicated that the As concentration in roots decreased significantly in flooded irrigation-treated plants at the harvest. Since water was withheld for about 10 
(a)



(b)

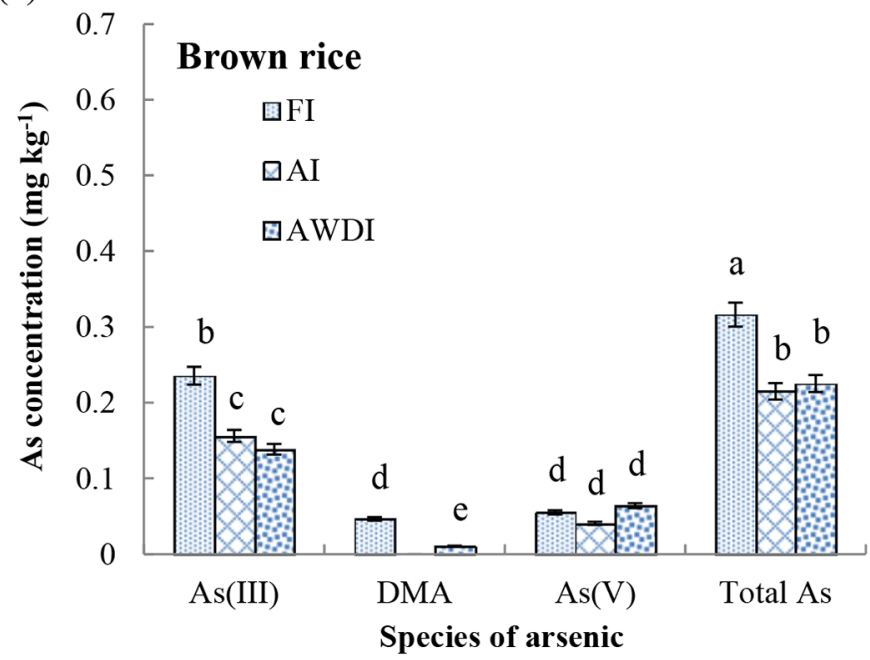

Figure 6. Effects of irrigation practices on arsenic speciation in (a) husks and (b) brown rice of rice plants grown in second cropping season of 2013. Error bars represent mean \pm standard error. Values above each column followed by the same letter(s) are not significantly different according to Fisher's least significant difference test at $p<0.05$. Fl, flood irrigation; Al, aerobic irrigation; AWDI, alternate wetting and drying irrigation; DMA, dimethylarsinate.

$\mathrm{d}$ to aid the maturity of rice grains (normal local cultivation practice), the transpiration stream may be involved. In addition, the highest As concentration in the roots of flooded irrigation-treated plants occurred in the anthesis stage (around 68 DAT) in both cropping seasons $(116.8 \pm 8.9 \mathrm{mg}$ $\mathrm{kg}^{-1}$ and $108.8 \pm 9.7 \mathrm{mg} \mathrm{kg}^{-1}$, respectively), when total leaf area was maximal (data not shown). Results suggest a close link of the uptake and accumulation of As in roots with the mass transpiration stream, by which the available water in the root zone is actively absorbed. No such phenomenon was observed with aerobic irrigation and AWDI, for which soil moisture was insufficient to meet the water demand. Therefore, transpiration may be a mechanism that determines the uptake and partitioning of As in rice plants.

From the viewpoint of the functions of redox conditions in the soil, as reported by Zhao et al. (2010) and
Roberts et al. (2011), the reductive dissolution of As-bearing iron oxyhydroxides under a flooded irrigation environment may release more adsorbed As and thus increase the availability of free As ions in soil solution, increasing As uptake rate by rice plants relative to that for ADWI and aerobic irrigation. In this study, the Eh values of groundwater and soil under flooded irrigation at the Hsuehchia experimental site were $-79 \pm-16 \mathrm{mV}$ (Table 1) and $-54 \pm-13 \mathrm{mV}$ (data not shown), respectively, indicating that groundwater and soil were in reducing conditions. The oxidation and reduction conditions of a paddy field were changed by irrigation practices, which led to different concentrations of As in the soil solution for different irrigation treatments, thereby influencing the uptake of As by plants. It is worthwhile to mention that the rapid fluctuation of soil redox potential with AWDI might limit the available As in the soil solution, lowering the As concentration in rice plant parts.

The As in paddy soil goes through a number of transformation processes under the normal flooded condition, such as reduction, desorption, methylation, and volatilization, leading to profound changes in the As bioavailability to plants. The solubility and bioavailability of As are influenced by direct or indirect redox reactions. The Asbearing iron oxides or hydroxides under reduction conditions release As and other elements. A flooded paddy field can increase As bioavailability to rice plants.

\section{Impact of Irrigation Practices on Arsenic Speciations in Husks and Brown Rice}

At maturity, the As concentration in husks and brown rice were changed by the type of irrigation practices using Ascontaminated groundwater in the two cropping seasons (Fig. 5 and 6). The As species in husks from rice plants treated with different irrigation practices in the first cropping season are shown in Fig. 5a. The As(V) level was higher than those of As(III) and DMA in husks in all irrigation practices in the first cropping season. The MMA concentration in husks and brown rice was not detectable (data not shown). Oparka and Gates (1984) reported that high As concentration in husks was due to the transpiration stream pulling As to the husks via the xylem channels in the vascular system. The As(III) level was higher than those of $\mathrm{As}(\mathrm{V})$ and DMA in brown rice under all irrigation practices in the first cropping season (Fig. 5b). A similar trend was found in the second cropping season, with $\mathrm{As}(\mathrm{V})$ being predominant in husks and $\mathrm{As}(\mathrm{III})$ being predominant in brown rice in all irrigation practices (Fig. 6a and 6b).

Geiszinger et al. (2002) and Kuehnelt et al. (2000) found that methylated As, especially DMA, accounted for a considerable proportion of the total As in rice grain. Monomethylarsonate was not detected in rice grain. Nissen and Benson (1982) found that many plants were able to methylate inorganic As, particularly under the conditions of $\mathrm{P}$ deficiency. Such findings imply that applying P-rich 
fertilizer to a paddy field could limit the methylation of inorganic As, leading to its reduction in the soil solution.

Li et al. (2006) and Lombi et al. (2009) showed that the As(III) complex forms in a large quantity with thiol peptides, and was controlled by the As(III) concentration in rice bran. In the present study, the concentration of As species in brown rice was in the order: $\mathrm{As}(\mathrm{III})>\mathrm{As}(\mathrm{V})>\mathrm{DMA}$; that in husks was in the order: $\mathrm{As}(\mathrm{V})>\mathrm{As}(\mathrm{III})>\mathrm{DMA}$. Li et al. (2009) found a considerable amount of organic As (e.g., DMA and MMA) in husks and brown rice, even though no organic As was detected in the soil solution. Similarly, the present study detected no DMA in paddy soil and found that As was methylated in the plants. The fractions of As(III), $\mathrm{As}(\mathrm{V})$, and DMA were 51 to 79,16 to 31 , and 5 to $18 \%$, respectively, in brown rice, and 13 to 36,61 to 83 , and 3 to $5 \%$, respectively, in husks (Fig. 5 and 6 ).

Results also show that the As concentration in husks and brown rice was the highest in flooded irrigationtreated plants (Fig. 5 and 6). The concentration levels of both $\mathrm{As}(\mathrm{III})$ and $\mathrm{As}(\mathrm{V})$ in brown rice with the flooded irrigation treatment were higher than those with the nonflooded irrigation practices, in which the concentration of $\mathrm{As}(\mathrm{III})$ was reduced by 43 to $62 \%$ and that of $\mathrm{As}(\mathrm{V})$ was reduced by 64 to $68 \%$. Larger amounts of irrigation groundwater were used in flooded irrigation treatment than the aerobic irrigation and AWDI irrigation practices. Similar results were observed for the two tested rice cultivars. Somenahally et al. (2011) reported a 41\% reduction in total grain As from rice grown on intermittently flooded fields relative to that from rice grown on flooded paddies. Sarkar et al. (2012) showed that the rapid fluctuation of reduced and oxidized environments in the rhizosphere soil was responsible for the significant decrease $(25 \%)$ in As load of rice grains under intermittent ponding compared with that under continuous ponding.

\section{Impact of Irrigation Practices on Grain Production and 1000-grain Weight}

Grain production is known to be regulated by the amount of irrigation water. For the Tainong 84 japonica rice cultivar used in first cropping season, grain production and amount of irrigation water from flooded irrigation (750 $\pm 41 \mathrm{~g} \mathrm{~m}^{-2}$ and $40.9 \mathrm{~m}^{3}$, respectively) plots were higher than those from aerobic irrigation $\left(420 \pm 32 \mathrm{~g} \mathrm{~m}^{-2}\right.$ and 18.5 $\mathrm{m}^{3}$, respectively) and AWDI (557 $\pm 38 \mathrm{~g} \mathrm{~m}^{-2}$ and $26.5 \mathrm{~m}^{3}$, respectively) plots (Table 3 ). The effect of irrigation practices was significant $(p<0.001$; data not shown) on grain production and 1000-grain weight. Similarly, grain production for Tainan 11 with flooded irrigation was $228 \pm 21$ $\mathrm{g} \mathrm{m}^{-2}$, higher than those obtained with aerobic irrigation $\left(420 \pm 32 \mathrm{~g} \mathrm{~m}^{-2}\right)$ and AWDI $\left(255 \pm 25 \mathrm{~g} \mathrm{~m}^{-2}\right)$. The 1000grain weight for Tainong 84 was $26.9 \mathrm{~g}$ with flooded irrigation, $21.1 \mathrm{~g}$ with aerobic irrigation, and $23.9 \mathrm{~g}$ with AWDI. Similar results were obtained for Tainan 11. Accordingly,
Table 3. Amounts of irrigation water used, 1000-grain weights, and grain productions for rice 'Tainong 84' and 'Tainan 11' for different irrigation practices (flood irrigation, aerobic irrigation, and alternate wetting and drying irrigation) grown in first and second cropping seasons (harvest) of 2013. Water use calculations do not include rainfall water.

\begin{tabular}{|c|c|c|c|c|c|}
\hline $\begin{array}{l}\text { Irrigation } \\
\text { practice }\end{array}$ & $\begin{array}{l}\text { Cropping } \\
\text { season }\end{array}$ & Cultivar & $\begin{array}{l}\text { Water } \\
\text { used }\end{array}$ & $\begin{array}{c}\text { 1000-grain } \\
\text { weight }^{\dagger}\end{array}$ & $\begin{array}{c}\text { Grain } \\
\text { production }\end{array}$ \\
\hline \multirow{3}{*}{$\begin{array}{l}\text { Flooded } \\
\text { irrigation }\end{array}$} & & & $\mathrm{m}^{3}$ & $g$ & $\mathrm{~g} \mathrm{~m}^{-2}$ \\
\hline & $1 \mathrm{st}$ & Tainong 84 & 40.9 & $26.9 \pm 4.3$ & $750 \pm 41$ \\
\hline & 2nd & Tainan 11 & 14.5 & $26.7 \pm 3.9$ & $288 \pm 21$ \\
\hline \multirow{2}{*}{$\begin{array}{l}\text { Aerobic } \\
\text { irrigation }\end{array}$} & $1 \mathrm{st}$ & Tainong 84 & 18.5 & $21.1 \pm 2.8$ & $420 \pm 32$ \\
\hline & 2nd & Tainan 11 & 16.0 & $24.7 \pm 2.5$ & $244 \pm 24$ \\
\hline \multirow{2}{*}{$\begin{array}{l}\text { Alternate } \\
\text { wetting } \\
\text { and drying } \\
\text { irrigation }\end{array}$} & $1 \mathrm{st}$ & Tainong 84 & 26.5 & $23.9 \pm 2.1$ & $557 \pm 38$ \\
\hline & 2nd & Tainan 11 & 24.8 & $24.9 \pm 2.9$ & $255 \pm 25$ \\
\hline
\end{tabular}

${ }_{1} 1000$-grain weight was measured from the dry weight of 1000 rice grains at the harvest.

$\ddagger$ Grain production was measured from the rice grain weight per area of $9 \mathrm{~m}^{2}$ at the harvest.

grain production and 1000-grain weight of both rice cultivars grown in the respective cropping seasons follow the order: flooded irrigation $>$ AWDI $>$ aerobic irrigation, with the difference between 8 and 43\% (Table 3).

A reduced yield under insufficient irrigation was reported by Abbasi and Sepaskhah (2011) and Hayashi et al. (2006). Linquist et al. (2015) indicated that yields increased by 1 to $13 \%$ and water use efficiency improved by 18 to $63 \%$ for well-watered treatments relative to deficit irrigation plots. Hayashi et al. (2006) showed that the lower grain yield from nonflooded fields was due to a lower number of spikelets per panicle, a smaller percentage of filled grains, and/or a lower 1000-grain weight. In the present study, in addition to a lower plant height and plant biomass, both grain production per unit area and 1000-grain weight decreased significantly when nonflooded irrigation treatments (AWDI and aerobic irrigation) were used, implying that the rice grain production potential of rice can be regulated by the amount of irrigation water input to paddy fields.

\section{CONCLUSIONS}

This study investigated the impacts of irrigation practices with As-contaminated groundwater on the extent of As accumulation within rice plant parts during development and rice grain production at maturity. Results show that the As concentration in rice plants varied with irrigation practice and growth stage. Generally, the levels of As in roots, leaf blades, shoots, husks, and brown rice were elevated by flooded irrigation. The accumulation and partitioning of As in rice plants followed the order: roots $>$ leaf blades $\geq$ shoots in the vegetative stages. Generally, rice plants grown under nonflooded irrigation practices had a lower As concentration as well as reduced grain production. Similar results were observed for the two tested 
japonica rice cultivars (Tainong 84 and Tainan 11). The concentration levels of As species in brown rice were in the order: of $\mathrm{As}(\mathrm{III})>\mathrm{As}(\mathrm{V})>\mathrm{DMA}$; those in husks were in the order: $\mathrm{As}(\mathrm{V})>\mathrm{As}(\mathrm{III})>\mathrm{DMA}$. Irrigation with higher amounts of As-contaminated groundwater led to higher As concentration in both husks and brown rice at maturity in both cropping seasons, which may be due to the greater amounts of As-contaminated groundwater input to the paddy fields and the anaerobic conditions that favor the release of As into the soil solution, which is uptaken by roots. For flooded irrigation treatment conducted at the experimental site, the total As concentration in brown rice was less than $0.45 \mathrm{mg} \mathrm{kg}^{-1}$ dry weight, yet exceeded the permissible limit $\left(0.2 \mathrm{mg} \mathrm{kg}^{-1}\right.$ dry weight $)$ set by the WHO. As a result, the type of irrigation practice should be taken into account to regulate the As concentration in rice plants, and control rice grain production. Arsenic in irrigation water is incorporated in Fe (hydr)oxide in soil during the nonflooded period, and it is quickly released from soil to water during the flooded period because of the reductive dissolution of the Fe (hydr)oxide phase and reduction of As from $\mathrm{As}(\mathrm{V})$ to $\mathrm{As}(\mathrm{III})$. Thus, flooded rice may contain high As concentrations compared with other grain crops. Water-saving irrigation practices can help conserve water resources and at the same time lower As concentration in rice. Bridging the gap between the volume of contaminated irrigation water and the levels of As within rice plants is the information required to set up a proper field practice for As-rich soils or fields irrigated with As-contaminated groundwater. This is a situation in which a difficult choice has to be made between rice production and As concentration level within rice plants through the adjustment of the amounts of As-contaminated irrigation water. However, this type of problem needs to be addressed by political decision rather than scientific results. In any case, this study provides decision-supporting evidence for the authority to make a policy decision.

\section{Acknowledgments}

The authors are grateful to the Ministry of Science and Technology of Taiwan for providing funding to support this study (MOST-A1030-0869). We thank the Chianan Irrigation Association of Taiwan for providing paddy fields for experiments. The authors are also very grateful to Mr. Ju-Hung Teng of National Cheng Kung University for his technical advice regarding the analysis of atomic absorption spectra. We thank Mr. Hui-Long Yang and Ms. Yi-Ting Chiou for their technical assistance in conducting the experiments.

\section{References}

Abbasi, M.R., and A.R. Sepaskhah. 2011. Response of different rice cultivars (Oryza sativa L.) to water-saving irrigation in greenhouse conditions. Intl. J. Plant Prod. 5:37-47.
Abedin, M.J., M.S. Cresser, A.A. Meharg, J. Feldmann, and J. Cotter-Howells. 2002a. Arsenic accumulation and metabolism in rice (Oryza sativa L.). Environ. Sci. Technol. 36:962-968. doi:10.1021/es0101678

Abedin, M.J., J. Feldmann, and A.A. Meharg. 2002b. Uptake kinetics of arsenic species in rice plants. Plant Physiol. 128:11201128. doi:10.1104/pp.010733

Bogdan, K., and M.K. Schenk. 2012. Arsenic mobilization in rice (Oryza sativa L.) and its accumulation in the grains. J. Plant Nut. Soil Sci. 175:135-141. doi:10.1002/jpln.201000426

Chou, M.-L., J.-S. Jean, G.-X. Sun, Z.-Y. Hseu, C.-M. Yang, S. Das, et al. 2014. Distribution and accumulation of arsenic in rice plants grown in arsenic-rich agricultural soil. Agron. J. 106:945-951. doi:10.2134/agronj13.0497

Garnier, J.M., F. Travassac, V. Lenoble, J. Rose, Y. Zheng, M.S. Hossain, et al. 2010. Temporal variations in arsenic uptake by rice plants: The role of iron plaque in paddy fields of Bangladesh irrigated with groundwater. Sci. Total Environ. 40:41854193. doi:10.1016/j.scitotenv.2010.05.019

Geiszinger, A., W. Goessler, and W. Kosmus. 2002. Organoarsenic compounds in plants and soil on top of an ore vein. Appl. Organomet. Chem. 16:245-249. doi:10.1002/aoc.294

Hayashi, S., A. Kamoshita, and J. Yamagishi. 2006. Effect of planting density on grain yield and water productivity of rice (Oryza sativa L.) grown in flooded and non-flooded fields in Japan. Plant Prod. Sci. 9:298-311. doi:10.1626/pps.9.298

IARC. 2004. Some drinking-water disinfectants and contaminants, including arsenic. In: IARC Monographs on the Evaluation of Carcinogenic Risks to Humans, Vol. 84. International Agency for Research on Cancer, Lyon, France.

Khan, M.A., M.R. Islam, G.M. Panaullah, J.M. Duxbury, M. Jahiruddin, and R.H. Loeppert. 2009. Fate of irrigation water arsenic in rice soils of Bangladesh. Plant Soil 322:263-277. doi:10.1007/s11104-009-9914-3

Kuehnelt, D., J. Lintschinger, and W. Goessler. 2000. Arsenic compounds in terrestrial organisms. IV. Green plants and lichens from an old arsenic smelter site in Austria. Appl. Organomet. Chem. 14:411-420. doi:10.1002/1099-0739(200008)14:8<411::AIDAOC24>3.0.CO;2-M

Kuramata, M., T. Abe, S. Matsumoto, and S. Ishikawa. 2011. Arsenic accumulation and speciation in Japanese paddy rice cultivars. Soil Sci. Plant Nutr. 57:248-258. doi:10.1080/00380768.

Li, Y.J., O.P. Dankher, L. Carreira, A.P. Smith, and R.B. Meagher. 2006. The shoot-specific expression of gamma-glutamylcysteine synthetase directs the long-distance transport of thiolpeptides to roots conferring tolerance to mercury and arsenic. Plant Physiol. 141:288-298. doi:10.1104/pp.105.074815

Li, R.Y., J.L. Stroud, J.F. Ma, S.P. McGrath, and F.J. Zhao. 2009. Mitigation of arsenic accumulation in rice with water management and silicon fertilization. Environ. Sci. Technol. 43:37783783. doi:10.1021/es803643v

Linquist, B.A., M.M. Anders, M.A.A. Adviento-Borbe, R.L. Chaney, L.L. Nalley, E.F.F. Da Rosa, et al. 2015. Reducing greenhouse gas emissions, water use, and grain arsenic levels in rice systems. Glob. Change Biol. 21:407-417. doi:10.1111/gcb.12701

Lombi, E., K.G. Scheckel, J. Pallon, A.M. Carey, Y.G. Zhu, and A.A. Meharg. 2009. Speciation and distribution of arsenic and localization of nutrients in rice grains. New Phytol. 184:193201. doi:10.1111/j.1469-8137.2009.02912.x

Marin, A.R., P.H. Masscheleyn, and W.H. Patrick. 1993. Soil redox$\mathrm{pH}$ stability of arsenic species and its influence on arsenic uptake by rice. Plant Soil 152:245-253. doi:10.1007/BF00029094 
Masscheleyn, P.H., R.D. Delaune, and W.H. Patrick. 1991. Effect of Redox potential and $\mathrm{pH}$ on arsenic speciation and solubility in a contaminated soil. Environ. Sci. Technol. 25:1414-1419. doi:10.1021/es00020a008

Meharg, A.A., and L. Jardine. 2003. Arsenite transport into paddy rice (Oryza sativa L.) roots. New Phytol. 157:39-44. doi:10.1046/j.1469-8137.2003.00655.x

Meharg, A.A., and F.-J. Zhao. 2012. Uptake of methylated arsenic species. In: Arsenic \& Rice. Springer, Dordrecht, the Netherlands. p. 110-113.

Nicholson, F.A., B.J. Chambers, J.R. William, and R.J. Unwin. 1999. Heavy metal contents of livestock feeds and animal manures in England and Wales. Bioresour. Technol. 70:23-31. doi:10.1016/S0960-8524(99)00017-6

Nissen, P., and A.A. Benson. 1982. Arsenic metabolism in freshwater and terrestrial plants. Physiol. Plant. 54:446-450. doi:10.1111/j.1399-3054.1982.tb00706.x

Oparka, K.J., and P. Gates. 1984. Sink anatomy in relation to solute movement in rice (Oryza-Sativa L.): A summary of findings. Plant Growth Regul. 2:297-307. doi:10.1007/BF00027289

Rahman, M.A., H. Hasegawa, M.M. Rahman, M.N. Islam, M.A.M. Miah, and A. Tasmen. 2007a. Effect of arsenic on photosynthesis, growth and yield of five widely cultivated rice (Oryza sativa L.) varieties in Bangladesh. Chemosphere 67:1072-1079. doi:10.1016/j.chemosphere.2006.11.061

Rahman, M.A., H. Hasegawa, M.M. Rahman, M.A.M. Miah, and A. Tasmin. 2008. Arsenic accumulation in rice (Oryza sativa L.): Human exposure through food chain. Ecotoxicol. Environ. Saf. 69:317-324. doi:10.1016/j.ecoenv.2007.01.005

Rahman, M.A., H. Hasegawa, M.M. Rahman, M.A. Rahman, and M.A.M. Miah. 2007b. Accumulation of arsenic in tissues of rice plant (Oryza sativa L.) and its distribution in fractions of rice grain. Chemosphere 69:942-948. doi:10.1016/j.chemosphere.2007.05.044

Rahman, R., A. Islam, and M.R. Khan. 2004. Arsenic-microbe interaction: A case study. Bangladesh J. Bot. 33:133-136.

Richards, M., and B.O. Sander. 2014. Alternate wetting and drying in irrigated rice: Implementation guidance for policymakers and investors. Research Program on Climate Change, Agriculture and Food Security. CGIAR/CCAFS/IRRI, FAO, Rome. Available at https://cgspace.cgiar.org/bitstream/ handle/10568/35402/info-note_CCAFS_AWD_final_ A4.pdf?sequence $=9$ (verified 11 Sept. 2015).

Roberts, L.C., S.J. Hug, A. Voegelin, J. Dittmar, R. Kretzschmar, B. Wehrli, et al. 2011. Arsenic dynamics in porewater of an intermittently irrigated paddy field in Bangladesh. Environ. Sci. Technol. 45:971-976. doi:10.1021/es102882q

Ruiz-Chancho, M.J., R. Sabe, J.F. Lopez-Sanchez, R. Rubio, and P. Thomas. 2005. New approaches to the extraction of arsenic species from soils. Mikrochim. Acta 151:241-248. doi:10.1007/ s00604-005-0405-9

Samanta, G., T.R. Chowdhury, B.K. Mandal, B.K. Biswas, U.K. Chowdhury, G.K. Basu, et al. 1999. Flow injection hydride generation atomic absorption spectrometry for determination of arsenic in water and biological samples from arsenic-affected districts of West Bengal, India, and Bangladesh. Microchem. J. 62:174-191. doi:10.1006/mchj.1999.1713

Sarkar, S., B. Basu, C.K. Kundu, and P.K. Patra. 2012. Deficit irrigation: An option to mitigate arsenic load of rice grain in West Bengal, India. Agric. Ecosyst. Environ. 146:147-152. doi:10.1016/j.agee.2011.10.008
Schoof, R.A., L.J. Yost, J. Eickhoff, E.A. Crecelius, D.W. Cragin, D.M. Meacher, et al. 1999. A market basket survey of inorganic arsenic in food. Food Chem. Toxicol. 37:839-846. doi:10.1016/ S0278-6915(99)00073-3

Seckler, D. 1996. The new era of water resources management: From "dry" to "wet" water savings. Res. Rep. 1. International Irrigation Management Institute, Colombo, Sri Lanka.

Somenahally, A.C., E.B. Hollister, W. Yan, T.J. Gentry, and R.H. Loeppert. 2011. Water management impacts on arsenic speciation and iron-reducing bacteria in contrastingrice-rhizosphere compartments. Environ. Sci. Technol. 45:8328-8335. doi:10.1021/es2012403

Sun, G.X., T. Van de Wiele, P. Alava, F. Tack, and G.L. Du. 2012. Arsenic in cooked rice: Effect of chemical, enzymatic and microbial processes on bioaccessibility and speciation in the human gastrointestinal tract. Environ. Pollut. 162:241-246. doi:10.1016/j.envpol.2011.11.021

Takahashi, Y., R. Minamikawa, K.H. Hattori, K. Kurishima, N. Kihou, and K. Yuita. 2004. Arsenic behavior in paddy fields during the cycle of flooded and non-flooded periods. Environ. Sci. Technol. 38:1038-1044. doi:10.1021/es034383n

Tseng, W.P. 1977. Effects and dose-Response relationship of skin cancer and Blackfoot disease with arsenic. Environ. Health Perspect. 19:109-119. doi:10.1289/ehp.7719109

Tseng, W.P. 1985. Blackfoot disease and skin cancer in an endemic area of chronic arsenicism in Taiwan. In: W.-P. Tseng, editor, Proc. of the Seminar on Environmental Toxicology, Taipei. 26 Mar.-2 Apr. 1985. Natl. Taiwan Univ. Hospital, Taipei, Taiwan. p. 142-155.

Tseng, W.P., W.Y. Chen, J.L. Sung, and J.S. Chen. 1961. A clinical study of Blackfoot disease in Taiwan: An endemic peripheral vascular disease. Proc. Seminar Environ. Toxicol. 3:1-8.

van de Hoek, W., R. Sakthivadivel, M. Renshaw, J.B. Silver, M.H. Birley, and F. Konradsen. 2001. Alternate wet/dry irrigation in rice cultivation: A practical way to save water and control malaria and Japanese encephalitis? Res. Rep. 47. International Water Management Institute. Colombo, Sri Lanka.

van Geen, A., Y. Zheng, Z. Cheng, H. Yi, R.K. Dhar, J.M. Garnier, et al. 2006. Impact of irrigation with groundwater elevated in arsenic on rice paddies in Bangladesh. Sci. Total Environ. 367:769-777. doi:10.1016/j.scitotenv.2006.01.030

Williams, P.N., A.H. Price, A. Raab, S.A. Hossain, J. Feldmann, and A.A. Meharg. 2005. Variation in arsenic speciation and concentration in paddy rice related to dietary exposure. Environ. Sci. Technol. 39:5531-5540. doi:10.1021/es0502324

Williams, P.N., A. Villada, C. Deacon, A. Raab, J. Figuerola, A.J. Green, et al. 2007. Greatly enhanced arsenic shoot assimilation in rice leads to elevated grain levels compared to wheat and barley. Environ. Sci. Technol. 41:6854-6859. doi:10.1021/es070627i

Xu, X.Y., S.P. McGrath, A.A. Meharg, and F.J. Zhao. 2008. Growing rice aerobically markedly decreases arsenic accumulation. Environ. Sci. Technol. 42:5574-5579. doi:10.1021/es800324u

Zhao, F.J., Y. Ago, N. Mitani, R.Y. Li, Y.H. Su, N. Yamaji, et al. 2010. The role of the rice aquaporin Lsi 1 in arsenite efflux from roots. New Phytol. 186:392-399. doi:10.1111/j.14698137.2010.03192.x 